\title{
DENDROMETRIC VARIABLES AND TRAUMATIC RESIN DUCTS IN PINE SPECIES ASSOCIATED WITH WOOD-STRIPPING: A tRADITIONAL PRACTICE IN THE CONIFER FORESTS OF CENTRAL MEXICO VARIABLES DENDROMÉTRICAS Y FORMACIÓN DE CANALES DE RESINA TRAUMÁTICOS EN ESPECIES DE PINO RELACIONADOS CON UNA PRÁCTICA FORESTAL TRADICIONAL EN EL CENTRO DE MÉXICO
}

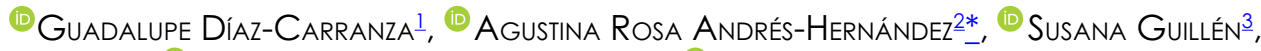

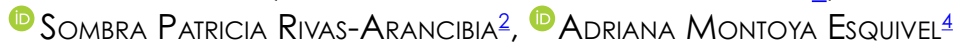

\author{
' Doctorado en Ciencias Biológicas, Universidad Autónoma de Tlaxcala, Tlaxcala, México. \\ ${ }^{2}$ Facultad de Ciencias Biológicas, Benemérita Universidad Autónoma de Puebla, Puebla, México. \\ ${ }^{3}$ Instituto de Investigaciones Forestales, Universidad Veracruzana, Xalapa, México. \\ ${ }^{4}$ Centro de Investigación en Ciencias Biológicas, Universidad Autónoma de Tlaxcala, Tlaxcala, México. \\ *Corresponding author: arahdm@yahoo.com.mx
}

\begin{abstract}
Background: In La Malinche National Park (LMNP), Pinus species are exploited mainly because they are a non-woody source of products such as ocote (resinous wood chips) and wood.

Questions/Objective: Which Pinus species are subjected to wood-stripping (WS) in the LMNP? What are their dendrometric characteristics? Do WS trees present traumatic resin ducts associated with the ocoteo practice? Does the number of trees subjected to WS increase with altitude? Study site and dates: La Malinche National Park; Tlaxcala, México, 2017-2018.

Methods: Random stratified sampling was done in a total of 33 plots in three different altitudes to quantify the number of damaged and undamaged trees and the total height and diameter per tree in each plot. Increment borers were obtained to estimate tree age, samples were taken for taxonomic determination, and tissue samples to evaluate mechanical damage.

Results: Pine species subjected to wood-stripping (ocoteo) were P. leiophylla, P. montezumae, P. pseudostrobus, and P. teocote, with P. montezumae being the most affected in high and mid altitudes. WS trees were those with the greatest diameter and with the largest number of traumatic resin ducts. The species having the highest number of traumatic resin ducts was $P$. teocote.

Conclusions: WS intensity in the LMNP is greater in the mid and low altitudes and in trees of greater diameter, height, and age. The species most affected by WS is $P$. montezumae and all WS individuals have a significantly higher number of traumatic resin ducts.

Keywords: forest resources, La Malinche National Park, ocoteo, resin ducts, temperate forest, traditional uses.

\section{Resumen}

Antecedentes: En el Parque Nacional La Malinche, las especies de Pinus se explotan principalmente por ser fuente de madera y recursos forestales no maderables como el ocote.

Preguntas/Objetivos: ¿Cuáles son las especies de pino que se ocotean en el PNLM? ¿Cuáles son sus características dendrométricas? ¿Los árboles presentan canales traumáticos asociados a la práctica de ocoteo? ¿El número de árboles sujetos a ocoteo incrementa dependiendo de la altitud?

Sitio de estudio y fechas: Parque Nacional La Malinche, Tlaxcala, México, 2017-2018.

Métodos: Se realizó un muestreo estratificado aleatorio con un total de 33 rodales en tres altitudes, cuantificando el número de árboles dañados y no dañados, altura total y diámetro. Se obtuvieron núcleos de crecimiento para estimar la edad de los árboles, se tomaron muestras para determinaciones taxonómicas y muestras de tejido para evaluar el daño mecánico.

Resultados: Las especies de pino sometidas a ocoteo fueron P. leiophylla, P. pseudostrobus, P. montezumae y P. teocote, siendo P. montezumae la más ocoteada en altitudes alta y media. Los árboles ocoteados fueron los de mayor diámetro y con mayor número de canales traumáticos. La especie que presentó más canales traumáticos fue $P$. teocote.

Conclusiones: La intensidad de ocoteo en el PNLM es mayor en altitudes media y baja y en árboles de mayor diámetro, altura y edad. La especie ocoteada con mayor intensidad es P. montezumae. Todos los individuos ocoteados presentan un mayor número de canales traumáticos.

Palabras clave: Bosque templado; canales de resina, ocoteo, Parque Nacional La Malinche, recursos forestales, usos tradicionales
\end{abstract}

This is an open access article distributed under the terms of the Creative Commons Attribution License CCBY-NC (4.0) international. https://creativecommons.org/licenses/by-nc/4.0/ 


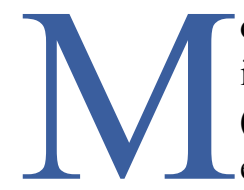

ore than three-quarters of the world's terrestrial biodiversity occurs in the forests and constitutes an invaluable socio-economical resource for millions of people worldwide, particularly in rural areas (FAO 2018). On a global level, forests are under pressure from biological processes and anthropic exploitation, even when they are located in Protected Natural Areas, Mexico is no exception (FAO 2018, Regil-García et al. 2020). Without proper management, anthropogenic pressures can produce adverse effects on forest structure and functionality (Gómez Díaz \&Villalobos 2020).

In Mexico, coniferous forests have a wide floristic and ecological diversity, that commonly occur in temperate and cold climates (Rzedowski 2006). In particular, pine forests cover $38 \%$ (6.15 million ha) of the country's forested land surface (Quintero-Gradilla et al. 2019). They are widely distributed throughout the mountain ranges of the Sierra Madre Occidental, the Sierra Madre Oriental, the Trans-Mexican Volcanic Belt, the Sierra Madre del Sur, and the Sierra de Oaxaca, covering a latitudinal gradient from Baja California to the Yucatan peninsula (Sánchez-González 2008). The pines are distributed from 100 to $4,200 \mathrm{~m}$ asl and $P$. hartwegii reaches up to $4,200 \mathrm{~m}$ asl (Galicia et al. 2015). The Trans-Mexican volcanic belt functions as a zone of diversification, endemism, and biogeographic transition between the Nearctic and Neotropical regions. With very particular geomorphic, geological and biotic characteristics, the complexity of its ecosystems favors the evolution of a great variety of floral endemism. It possesses a large proportion of pine species and 21 out of 43 the endemic species of Mexico stands there (Rzedowski 1978, Fa \& Morales 1991, Farjón et al. 1997, Villaseñor et al. 2007, Gernandt \& Pérez-de la Rosa 2014, Halffter \& Morrone 2017, Morrone 2019).

La Malinche National Park (hereinafter LMNP), a mountain located in the Trans-Mexican Volcanic Belt, is home to a wide diversity of pine species, including Pinus hartwegii Lindl., Pinus leiophylla Schiede ex Schltdl. $\&$ Cham., P. montezumae Lamb., P. pseudostrobus Lindl., and P. teocote Schiede ex Schltdl. Furthermore, reforestation programs have introduced $P$. strobiformis Engelm and $P$. patula Schiede ex Schltdl. \& Cham. to the National Park. These species are distributed over the mountain, generally in monospecific fragmented stands or in clusters at elevations of between 2,000 and 4,000 m. P. leiophylla is characteristic of pine forests at elevations below 2,500 m, mostly as mixed forest. P. montezumae is the dominant species between 2,500 and 3,100 m and it may be found with P. pseudostrobus, P. teocote and various species of Abies and Quercus. At elevations of 3,500 to $4,200 \mathrm{~m}$, there is a community of $P$. hartwegii (López-Domínguez \& Acosta Pérez 2005, Rojas-García \& Villers-Ruíz 2005, Suárez-Mota et al. 2013, Arriola Padilla et al. 2014). The most exploited species in the LMNP are pines, because the habitants of rural settlements use these species to obtain different resources, such as firewood, wood, bark, resin, and ocote (resinous wood chips), among others (Espejel 1996, Espejel Rodríguez et al. 2001).

Over the last 60 years, the combined effects of illegal and authorized commercial logging of conifers in the LMNP has led to a reduction of over $50 \%$ of the 30,000 ha of forested land surface that existed in 1936. Currently, there are only 15,000 a of forest and $77 \%$ of the vegetation exhibits certain degree of damage due to the impact of human activities, mainly logging, intentional and unintentional fires, and wood-stripping, a traditional practice known as "ocoteo" (Werner 1990, Espejel 1996, Espejel Rodríguez et al. 2001, Espejel Rodríguez et al. 2004). Ocoteo consists of manually cutting off strips of wood and bark impregnated with resin (Rzedowski 2006). A series of cuts are made in the trunk until a large wound with a depth of 5 to $10 \mathrm{~cm}$ is formed, more than two meters above ground level. Additionally, this practice often involves setting a fire at the base of the tree to increase resin flow from the wound (Veblen 1982). This traditional practice has been used in Mexico for decades, and it is an essential economic activity for many rural communities (Montero López et al. 2016, Molina-Luna \& Arellanes Cancino 2016). The demand for "ocote" is due to its effectiveness as a fire starter in traditional stoves, ovens (Martínez 1992, Espejel 1996) and, more recently, tourist campfires. Records of this practice can be found since pre-Hispanic times in many lowland Mayan sites such as Tikal and Chinikiha in Chiapas and Belize (Montero López et al. 2016).

Although ocoteo is common in Mexico's pine forests, no study has evaluated the damage it causes, and it is uncertain if the persons which practices this activity have a preference for trees with specific dendrometric characteristics 
(DBH, height, and age). Some authors report that the purposes of ocoteo are to (1) obtain ocote for domestic use, (2) sell ocote in local markets, and (3) cause mechanical damage to trees to gradually weaken them until they die, in an attempt to find a "legal" way of simulating a natural death and extracting the natural resource (Werner 1990, Espejel Rodríguez et al. 2001). It is unknown to what extent the practice of ocoteo affects forests. However, this practice is deemed harmful and it represents an important factor in the loss of forest cover (Martínez 1992, Werner 1990, Rzedowski 2006).

Furthermore, studies have shown that when pine trees are mechanically damaged, traumatic ducts form in the wood as a reaction. There are fewer of these ducts in trees that have not been damaged (Nagy et al. 2004, Franceschi et al. 2005, Luchi et al. 2005, Krokene et al. 2008, Rodríguez-García et al. 2014).

The purpose of this study is to assess the damage done by ocoteo to different pine species found in the LMNP by making: (a) an estimation of ocoteo intensity at different altitudes according to the distribution of pine species and their associations on the mountain; (b) a comparison of dendrometric variables between wood-stripped (WS) and non-wood-stripped (NWS) trees; (c) a histological comparison of the presence and number of traumatic ducts in WS and NWS trees.

The research questions were: Which pine species are subjected to wood-stripping in the LMNP? What are the dendrometric characteristics of WS trees compared to NWS trees? Do WS trees present more traumatic ducts than NWS? Does the number of trees subjected to wood-stripping in the LMNP increase or decrease with altitude?

\section{Materials and methods}

Study area. The LMNP is located in the States of Tlaxcala and Puebla in the eastern central region of Mexico at $19^{\circ}$ $06^{\prime} 30^{\prime \prime}-19^{\circ} 20^{\prime} 1^{\prime \prime} \mathrm{N}$ and $97^{\circ} 55^{\prime} 32^{\prime \prime}-98^{\circ} 09^{\prime} 55^{\prime \prime} \mathrm{W}$, at 2,300-4,461 $\mathrm{m}$ asl. It is one of the central volcanic landforms of the Trans-Mexican Volcanic Belt. It has an area of 46,093 ha, 33,161 ha of which are in the state of Tlaxcala and 12,932 ha in the State of Puebla. The Park contains about $37 \%$ of the forested land in the State of Tlaxcala. Abies, Pinus, and Quercus are the dominant genera in forest stands in the lower parts of the LMNP. The climate is mild sub-humid, with summer rains, an average annual rainfall between 1,000 and 1,200 $\mathrm{mm}$, and soils with variable composition derived from volcanic eruptions where lithosol, andosol, regosol, fluvisol, and luvisol predominate (Espejel-Rodríguez et al. 1999, López-Domínguez \& Acosta Pérez 2005, Villers Ruiz et al. 2006).

Fieldwork. The LMNP was divided into three altitudes: low (2,000 to 2,500 m), mid (2,500 to 3,000 m), and high $(3,000$ to $3,500 \mathrm{~m}$; Figure 1) with 33 randomly selected circular plots within the three altitudes. Each plot had an area of $400 \mathrm{~m}^{2}$ and a radius of $11.28 \mathrm{~m}$ (Schlegel et al. 2001, CONAFOR 2010). Sampling was done in 2017 and 2018. Each plot's center point was georeferenced, and all trees with a diameter $\geq 10 \mathrm{~cm}$ at breast-height $(1.3 \mathrm{~m})$ were counted (Schlegel et al. 2001, Vargas Larreta 2013, Kometter 2005). Tree height was measured using a Suunto clinometer (PM-5/360 degree/percentage) (Kometter 2005, Romahn de la Vega \& Ramírez 2010).

To count the growth rings, cores were obtained from 193 trees located in the 33 plots of the LMNP; the extractions were made at a breast height of $1.3 \mathrm{~m}$ using a $5.15 \mathrm{~mm}$ Pressler increment borer (Haglöf Inc., Madison, MS, USA). After obtaining the cores, the drilled holes were sealed with Campeche wax (Rojas-García \& Villers-Ruíz 2005, Gutiérrez \& Ricker 2014). Then each core was placed in a plastic straw, marked, and taken to the laboratory for analysis.

From the 193 samples, four NWS individuals of each species across the different altitudes (a total of 28 samples) were sampled to study the traumatic ducts in the wood. Sample was taken at a breast height of $1.3 \mathrm{~m}$, bark was removed and using a saw a piece of wood removed. In the case of WS trees, samples from the middle of the ocoteo wound were taken from 1-4 individuals of each species (20 samples) across the different altitudes (RodríguezGarcía et al. 2014). All samples were fragmented to a size of 3-5 $\mathrm{cm}^{3}$ and were fixed in a formalin $10 \mathrm{ml}(37 \%$ formaldehyde)-glacial acetic acid $5 \mathrm{ml}$-ethanol (96\%) $50 \mathrm{ml}$ - water $35 \mathrm{ml}$, mixture solution (Krommenhoek et al. 1986). The list of species is shown in Table 1. 


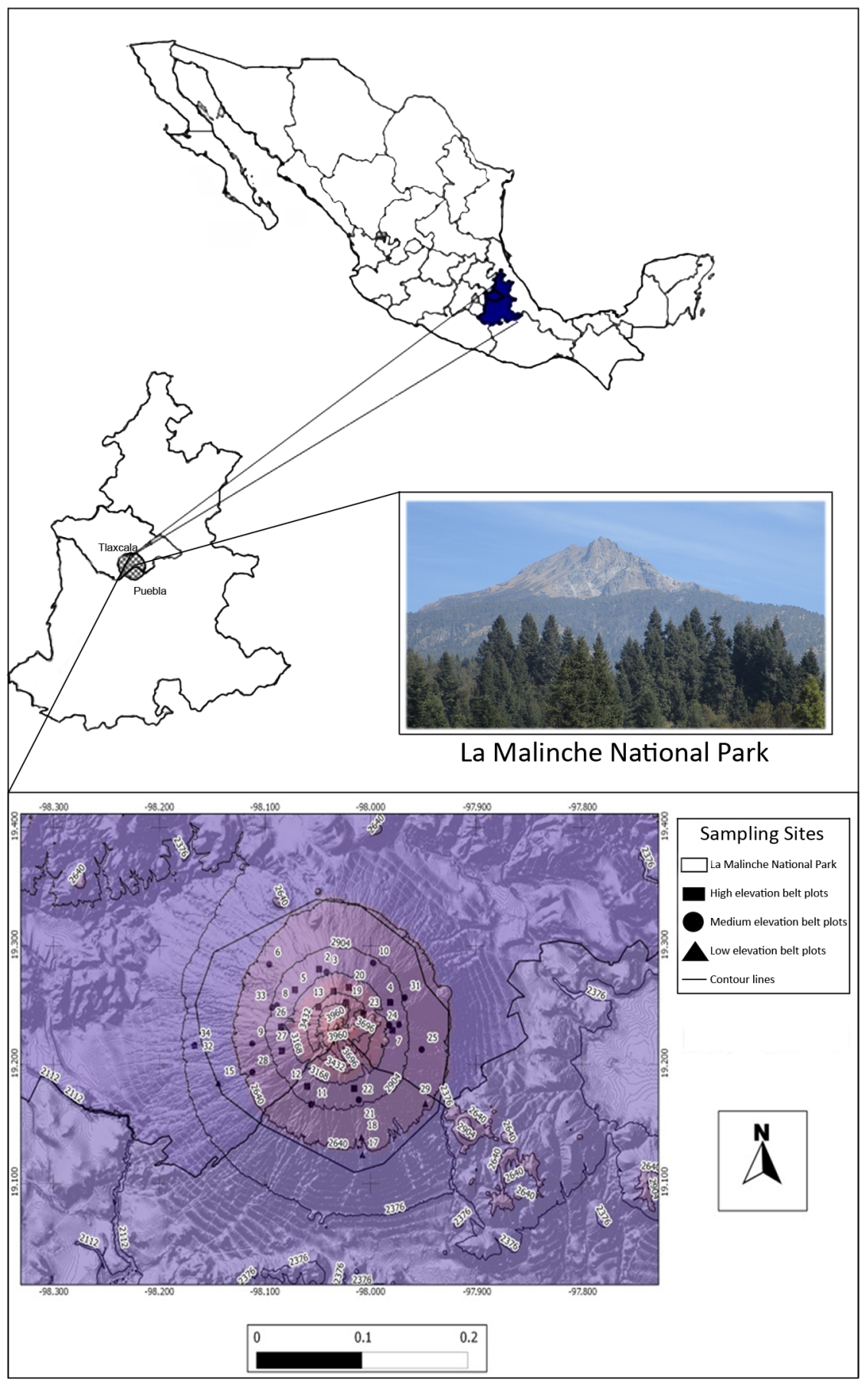

Figure 1. Location of La Malinche National Park in Tlaxcala, and central Mexico.

Laboratory work. Taxonomic keys available in the literature were used for taxonomical determination botanical species. Two samples of leaves and strobiles were taken from each WS tree (Martínez 1992, Villers Ruíz et al. 2006, RamosDorantes et al. 2017). Samples were housed in the National Herbarium (MEXU).

Tree age was estimated by counting growth rings (Fritts 1976). For this process, the collected cores were dried in an oven (Ecoshel-HV-50, VelaQuin, México) at $23{ }^{\circ} \mathrm{C}$ for 48 hours following the criteria of Speer (2010) and Gutiérrez \& Ricker (2014). Once dried, the cores were mounted on wooden bases and polished to discriminate between growth ring boundaries; afterwards, the identified rings were counted (Speer 2010). 
Evaluation of wood-stripping in pine species in Mexico

Table 1. The ocoteo practice (percentage) intensity registered in pine species on three elevations of the LMNP.

\begin{tabular}{|c|c|c|c|c|c|c|c|c|}
\hline Altitude & $\begin{array}{l}\text { Number } \\
\text { of plots }\end{array}$ & $\begin{array}{l}\text { Number } \\
\text { of pine } \\
\text { trees }\end{array}$ & $\begin{array}{c}\text { Total } \\
\text { WS trees }\end{array}$ & WS species & $\begin{array}{c}\text { Number of } \\
\text { WS trees by } \\
\text { species }\end{array}$ & $\begin{array}{c}\text { Average of WS } \\
\text { individuals by } \\
\text { plot }\end{array}$ & $\begin{array}{c}\text { Specific } \\
\text { percentage } \\
\text { of WS trees }\end{array}$ & $\begin{array}{c}\text { Absolute } \\
\text { percentage } \\
\text { of WS trees }\end{array}$ \\
\hline \multicolumn{9}{|l|}{ Low } \\
\hline $\begin{array}{l}(2,000- \\
2,500 \mathrm{~m})\end{array}$ & 7 & 79 & 8 & P. leiophylla & 8 & $1.3 \pm 0.1$ & $100 \%$ & $10.1 \%$ \\
\hline Medium & \multirow{3}{*}{14} & \multirow{3}{*}{171} & \multirow{3}{*}{27} & P. montezumae & 22 & $3.1 \pm 0.9$ & $81.4 \%$ & \multirow{3}{*}{$15.7 \%$} \\
\hline \multirow{2}{*}{$\begin{array}{l}(2,500- \\
3,000 \mathrm{~m})\end{array}$} & & & & P. leiophylla & 2 & $1 \pm 0$ & $7.4 \%$ & \\
\hline & & & & P. pseudostrobus & 3 & $1 \pm 0.4$ & $11.1 \%$ & \\
\hline High & \multirow{3}{*}{12} & \multirow{3}{*}{149} & \multirow{3}{*}{12} & P. montezumae & 9 & $1.7 \pm 0.2$ & $75.0 \%$ & \multirow{3}{*}{$8.0 \%$} \\
\hline \multirow{2}{*}{$\begin{array}{l}(3,000- \\
3,500 \mathrm{~m})\end{array}$} & & & & P. pseudostrobus & 2 & $2 \pm 0$ & $16.6 \%$ & \\
\hline & & & & P. teocote & 1 & $1 \pm 0$ & $8.3 \%$ & \\
\hline
\end{tabular}

(WS) wood-stripped.

Transverse sections of $25 \mu \mathrm{m}$ were obtained using a sliding microtome (pfm AG-50996-Germany). Sections were stained with safranin and mounted in synthetic resin (Krommenhoek et al. 1986). The ducts were counted in 25 fields of $1 \mathrm{~mm}^{2}$ for each individual, without discriminating between growth rings.

Analyses. For the evaluation of ocoteo, the dependent variables were intensity, percentage, and dendrometric characteristics (DBH, height, age, and the number of traumatic ducts) of the WS and NWS trees in different elevations.

The intensity of wood-stripping (ocoteo) on pine species at each altitude was estimated based on the relative percentage of WS trees per altitude, which was calculated with the following equation: Absolute percentage of WS trees $=($ Number of WS trees/Total number of registered trees $) \times 100$. The following equation was used for wood-stripping intensity for different species in each elevation: Specific percentage of WS trees $=($ Number of WS trees of each species/Total number of WS trees) $\times 100$.

The relative frequency of ocoteo in each species per altitude was calculated by: $h_{i}=f_{i} / \mathrm{N}$, where $h_{i}=$ Relative frequency of the $i$ th observation, $f_{i}=$ Absolute frequency of the $i$ th observation, $N=$ Total number of observations.

To determine whether the dendrometric characteristics of WS and NWS trees (DBH, height, and age) had any influence on ocoteo in the different elevations on the mountain, different statistical analyses were performed according to the type of the response variable. The DBH data was normalized with a logarithmic transformation and was compared using one-way ANOVA and Fisher's least-significant-difference method (statistically significant differences were considered at $P<0.05$ ) followed by post-hoc Tukey-Kramer test. Height data were analyzed using a non-parametric Kruskal-Wallis test with the Dunnett test's respective multiple comparison tests (Zar 1999).

Tree age analysis was performed using a Generalized Linear Model (GLM) with Poisson error distribution and a logarithmic link function. The predictor variables were the altitude (low, medium, high), the tree species (P. montezumae, P. leiophylla, P. pseudostrobus, and P. teocote), and the presence or absence of wood-stripping (ocoteo) marks. Wood-stripping in WS pine species was evaluated using the same type of GLM. In these models, the resin duct predictive variables were: Species, Wood-stripping (ocoteo), and Individuals. The Species variable includes 
P. montezumae, P. leiophylla, P. pseudostrobus, and P. teocote. P. hartwegii was removed from the model because no WS specimens were found. The wood-stripping (ocoteo) variable includes both WS and NWS trees of the same species. The Individual variable (variation between individuals). Of the different models generated, the simplest or most parsimonious was selected so that non-significant explanatory variables were eliminated during the process. The statistical significance for each factor was determined by means of a deviance analysis and evaluation of how well the data fit the model.

Statistical analyses of the dendrometric variables (DBH and height) of WS and NWS trees were performed done using NCSS Statistical Program v10.0, NCSS 2015 (Hintze 2008). Analysis of the number of traumatic ducts and the species and ages of trees was done using R language v3.01, (R Core Team 2015, Crawley 2013).

\section{Results}

Intensity of wood-stripping (ocoteo). The intensity of the practice of ocoteo in the LMNP was higher in the mid altitude, with an absolute percentage of $15.7 \%$; values of $8.0 \%$ and $10.1 \%$ were recorded at high and low altitudes, respectively (Table 1), P. montezumae was the species most affected ocoteo at high and mid altitudes, no ocoteo was observed in $P$. hartwegii, only found at the highest altitudes. In the lowest altitudes, ocoteo was observed only by $P$. leiophylla trees (Table 1).

Comparison of dendrometric characteristics in WS and NWS trees. The DBH diameter of WS and NWS trees increased with altitude. The analysis of variance showed significant differences $\left(F_{5,5}=5.07, P<0.001\right)$ in the DBH diameter of WS and NWS trees in high and mid altitudes (Figure 2A). In the LMNP, the tallest trees were those subjected to wood-stripping (Table 2). Significant differences were found between the heights of WS and NWS trees $\left(\chi^{2}\right.$ $=51.6$ and $P<0.001)$ in high and mid altitudes (Figure $2 \mathrm{~B})$. The average age of WS trees in mid and low altitudes was greater than NWS trees. At high altitudes WS trees were youngest (Table 2). Deviance analysis revealed no significant differences (Deviance $=0.14, \mathrm{df}=2, P>0.05$ ) between tree age among altitudes.

Comparison of dendrometric characteristics between tree species subjected to wood-stripping (ocoteo). DBH. The WS
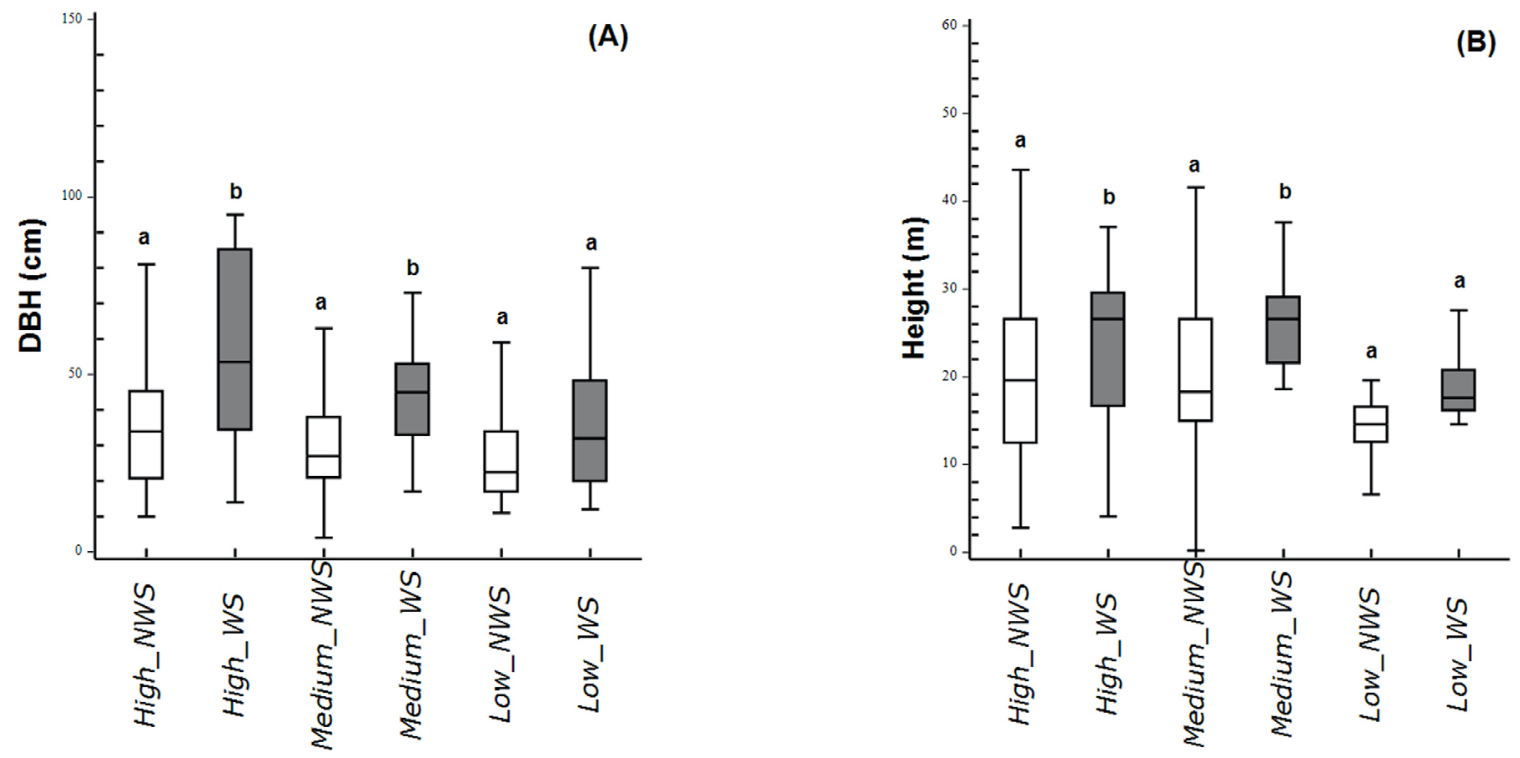

Figure 2. Dendrometric characteristics. (A) DBH; (B) Height in different species of Pinus. Different letters show significant differences $(P<0.05)$ between WS and NWS trees on the mountain's same elevation belt. 
Evaluation of wood-stripping in pine species in Mexico

Table 2. Dendrometric characteristics between WS and NWS trees registered on three elevations of the LMNP.

\begin{tabular}{|c|c|c|c|c|c|c|}
\hline \multirow[t]{2}{*}{ Altitude } & \multicolumn{2}{|c|}{ DBH (cm) } & \multicolumn{2}{|c|}{ Height (m) } & \multicolumn{2}{|c|}{ Age (years) } \\
\hline & NWS & WS & NWS & WS & NWS & WS \\
\hline$n$ & 277 & 47 & 277 & 47 & 147 & 47 \\
\hline \multicolumn{7}{|l|}{ Low } \\
\hline$(2,000-2,500 \mathrm{~m})$ & $26 \pm 2$ & $36 \pm 6$ & $12 \pm 1$ & $18 \pm 3$ & $48 \pm 3$ & $65 \pm 7$ \\
\hline \multicolumn{7}{|l|}{ Medium } \\
\hline$(2,500-3,000 \mathrm{~m})$ & $32 \pm 1$ & $46 \pm 3$ & $19 \pm 0.6$ & $26 \pm 1$ & $40 \pm 2$ & $54 \pm 4$ \\
\hline \multicolumn{7}{|l|}{ High } \\
\hline$(3,000-3,500 \mathrm{~m})$ & $27 \pm 1$ & $57 \pm 5$ & $14 \pm 0.7$ & $24 \pm 2$ & $48 \pm 2$ & $39 \pm 6$ \\
\hline
\end{tabular}

species with the greatest diameter were P. pseudostrobus found at mid altitude, followed by $P$. montezumae at high altitude. The WS species with the smallest diameter was P. leiophylla (Table 3). No significant differences were found between species' DBH among altitudes (Figure 3A).

Height.- The tallest WS trees were $P$. leiophylla trees found at mid altitude. The smallest WS trees were $P$. leiophylla, but located at low altitude (Table 3), and Kruskal-Wallis showed no significant differences ( $\underline{\text { Figure } 3 \mathrm{~B}})$.

Age.- The oldest trees subjected to wood-stripping (ocoteo) were P. leiophylla, found at mid and low altitudes. The youngest WS trees were located at high altitude and belong to $P$. pseudostrobus and $P$. montezumae (Table 3 ). Deviance analysis showed significant differences in the age of WS species (Deviance $=0.003, \mathrm{df}=3, P<0.01$ ), in the interaction of Elevation $\times$ Species $($ Deviance $=0.031, \mathrm{df}=3, P<0.01)$ and in the interaction Species $\times$ Woodstripping (ocoteo) (Deviance $=0.003, \mathrm{df}=3, P<0.01)$.

Traumatic resin ducts. - Many more traumatic ducts were recorded in WS trees than NWS ones (Table 4). The

Table 3. Dendrometric characteristics in WS trees registered on three elevations of the LMNP.

\begin{tabular}{llcccc}
\hline Altitude & \multicolumn{1}{c}{ Species } & $\begin{array}{c}\text { DBH } \\
(\mathbf{c m})\end{array}$ & $\begin{array}{c}\text { Height } \\
(\mathbf{m})\end{array}$ & $\begin{array}{c}\text { Age } \\
(\mathbf{y e a r s})\end{array}$ & n \\
\hline Low & & & & & \\
$(2,000-2,500 \mathrm{~m})$ & Pinus leiophylla & $36 \pm 6$ & $19 \pm 2$ & $62 \pm 6$ & 8 \\
Medium & Pinus pseudostrobus & $83 \pm 10$ & $25 \pm 4$ & $53 \pm 10$ & 3 \\
$(2,500-3,000 \mathrm{~m})$ & Pinus montezumae & $42 \pm 4$ & $25 \pm 1$ & $49 \pm 4$ & 22 \\
& Pinus leiophylla & $22 \pm 13$ & $28 \pm 5$ & $104 \pm 12$ & 2 \\
High & Pinus montezumae & $62 \pm 6$ & $23 \pm 2$ & $38 \pm 6$ & 9 \\
$(3,000-3,500 \mathrm{~m})$ & Pinus teocote & $38 \pm 18$ & $28 \pm 7$ & $62 \pm 18$ & 2 \\
& Pinus pseudostrobus & $45 \pm 12$ & $26 \pm 5$ & $35 \pm 12$ & 2 \\
\hline
\end{tabular}

$\overline{(\mathrm{DBH}) \text { diameter at breast height; average values ( } N=48 \text { trees); sample size }(n) \text { and }}$ standard error. 

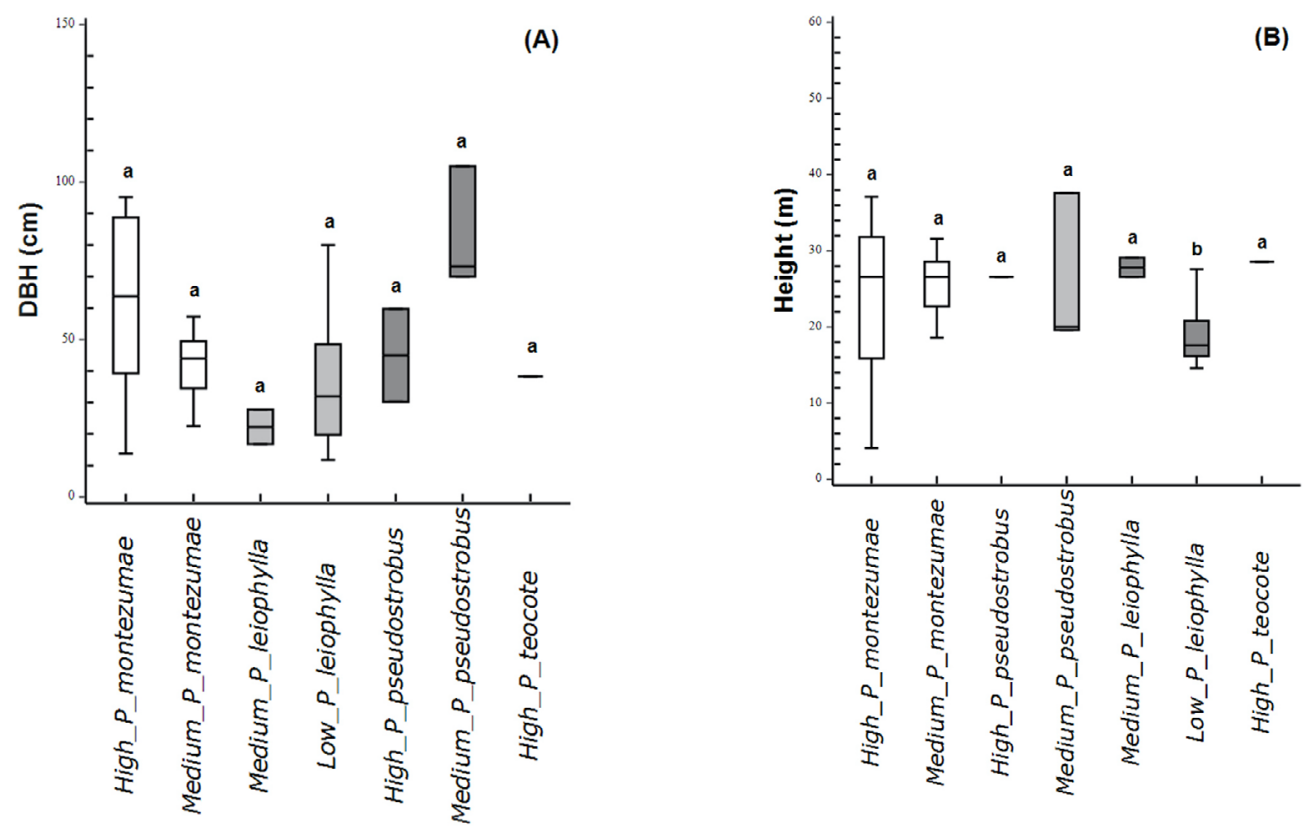

Figure 3. Dendrometric characteristics. (A) DBH of WS trees; (B) height in different species of WS Pinus. Different letters show significant differences $(P<0.05)$ between the same species on other mountain elevational belts.

highest number of traumatic ducts per $\mathrm{mm}^{2}$ were present in P. teocote followed by $P$. leiophylla, P. montezumae, and P. pseudostrobus (Table 4 and Figure 4A-I). Deviance analysis showed significant differences in the number of traumatic ducts between WS and NWS trees (Deviance $=8.96 \mathrm{e}-13, \mathrm{df}=3, P<0.001$ ) and between species subjected to WS (Deviance $<2.2 \mathrm{e}-16, \mathrm{df}=3, P<0.001)$.

\section{Discussion}

Table 4. Number (average \pm standard error) of traumatic ducts counted per $\mathrm{mm}^{2}$ in individuals of different Pinus species WS and NWS, registered in LMNP.

\begin{tabular}{lcc}
\hline Species & $\begin{array}{c}\text { Number of traumatic resin ducts in Pinus species } \\
\text { NWS }\end{array}$ \\
\hline Pinus montezumae & $19 \pm 7$ & $39 \pm 7$ \\
Pinus leiophylla & $23 \pm 5$ & $51 \pm 8$ \\
Pinus pseudostrobus & $12 \pm 5$ & $13 \pm 2$ \\
Pinus teocote & $11 \pm 0.9$ & $98 \pm 18$ \\
Pinus hartwegii & $16 \pm 16$ & $* * *$ \\
\hline
\end{tabular}

*** The species was identified in the LMNP. However, there were no found WS trees. 

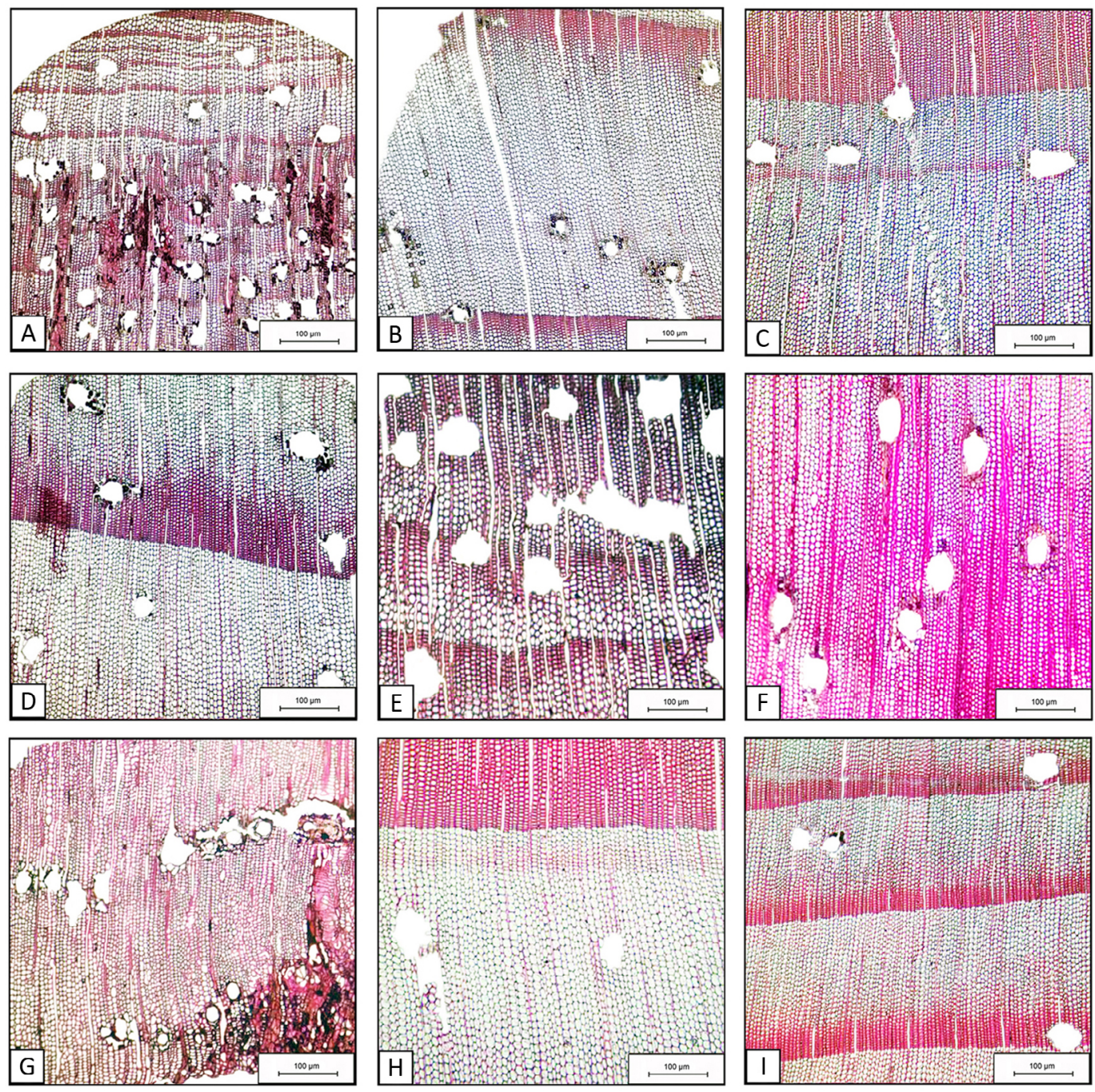

Figure 4. Histological damage of Pinus species subjected to wood-stripping (ocoteo) WS and NWS trees. (A-B) Pinus teocote, (C-D) P. leiophylla, (E-F) P. montezumae, (G-H) P. pseudostrobus, I). Damage was not observed in P. hartwegii.

This study showed that the practice of wood-stripping in the LMNP mainly affects to P. leiophylla, P. montezumae, $P$. pseudostrobus, and $P$. teocote. No trees of $P$. hartwegii were found to have been subjected to wood-stripping. $P$. montezumae and P. leiophylla were the species with the highest number of trees showing evidence of wood-stripping, although in the latter species the practice was less intense. The results showed that the practice of wood-stripping in the LMNP is associated with the natural distribution of the Pinus species from 2,000 to 4,000 m; also with their abundance at different altitudes.

Rojas-García \& Villers-Ruíz (2008) have reported that the most abundant species in the LMNP are P. montezumae and $P$. leiophylla, in association with $P$. pseudostrobus and $P$. teocote. Our study supported that report; the presence of $P$. montezumae at the mid altitude explains why the largest number of WS trees belong to this species. P. leiophylla is found below 2,900 $\mathrm{m}$ asl and predominantes at mid and low altitudes. According to López-Domínguez \& Acosta Pérez (2005) P. leiophylla predominates below $2,500 \mathrm{~m}$ asl, which explains the results obtained showing that $P$. leiophylla was the only species subjected to wood-stripping at the low altitude.

According to Zamora-Campos et al. (2007), P. montezumae has wide natural distribution throughout the Mexican 
Republic. It is also the most chosen source of timber in the country, mainly in the Trans-Mexican Volcanic Belt. Wood-stripping is very important to the people who live in the vicinity of the volcano in the LMNP, which was evident in this study (Figure 5A-D).

The results of this study show that the practice of ocoteo in the LMNP is performed predominantly on trees with
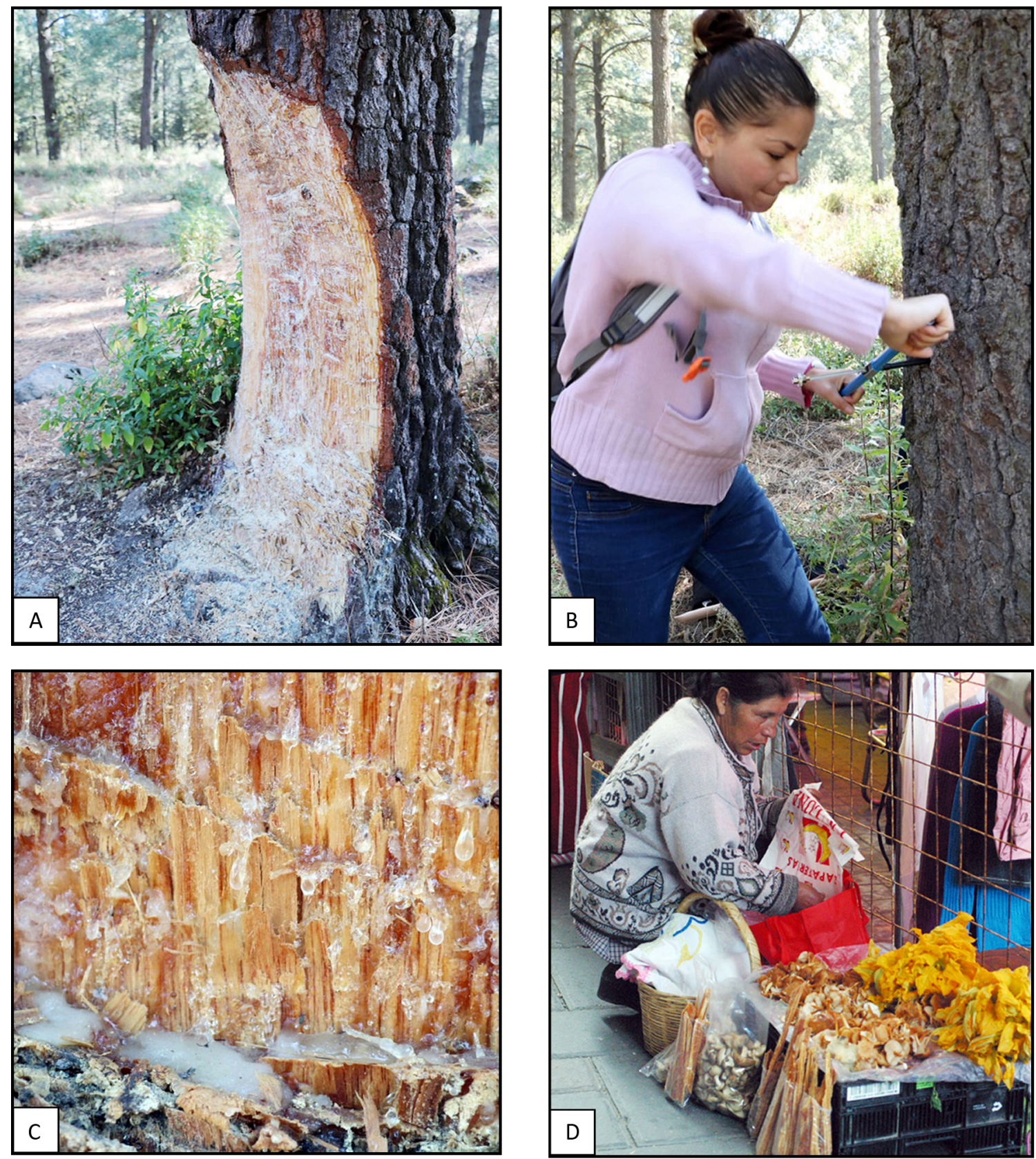

Figure 5. (A, B, C) Pinus trees under wood-stripped on La Malinche National Park; (D) selling ocote in the Huamantla local market.

greater DBH (low $36 \pm 6$, mid $46 \pm 3$, high $57 \pm 5$ ), with greater height (low $18 \pm 3$, mid $26 \pm 1$, high $24 \pm 2$ ), and with respect to age only at low and mid altitudes (low $65 \pm 7$, mid $54 \pm 4$ ). These results suggest that the people who use this resource empirically select the most robust and tallest trees because they offer ocote strips of higher quality. According to people living in the vicinity, the amount of resin is higher in these trees (personal communication). 
Particularly, López Rucuch (1996) found a positive correlation between trunk diameter and the amount of resin produced by for P. oocarpa and P. pseudostrobus.

Other studies have positively related wound size to resin production in pine trees (Schweingruber 1996, Mumm \& Hilker 2006, Granados-Sánchez et al. 2008, Bohlmann 2008, Hadiyane et al. 2015, Reyes-Ramos et al. 2016). The results obtained in this study showed that wood-stripping causes an increase in the number of traumatic ducts. The species with the highest number of traumatic ducts was $P$. teocote followed by $P$. leiophylla. The increase in the number of traumatic ducts is a natural response from Pinus trees. The number of traumatic ducts increases after the trees have gone through a period of stress caused by mechanical damage (Luchi et al. 2005, Franceschi et al. 2005, Moreira Tomé et al. 2008, Sampedro et al. 2011, Ferrenberg et al. 2014, Zas et al. 2014). According to Sampedro et al. (2011) the increase in the formation of traumatic ducts induces the use of a large amount of energy to drive defense systems and other functions associated with growth and reproduction.

The results obtained reveal that the trees selected for wood-stripping in the LMNP are more robust and taller individuals, while tree age varies according to altitude. Younger trees at a higher altitude and older trees at mid and low altitudes are selected for wood-stripping. The fact that age is not a tangible characteristic for the selection of individual trees for ocoteo may explain the lack of a clear relationship between tree age and the presence of woodstripping marks.

\section{Acknowledgments}

We would like to express our gratitude and appreciation to the residents and authorities of La Malinche National Park for the facilities they provided in support of this investigation, and to Carolina Cámara Beristaín, Ernesto Sianya Díaz López, and Alondra Cuatlaxe for their support in the field. This work forms part of the first author's doctoral thesis and was funded by a doctoral scholarship granted by CONACYT. Heartfelt thanks go to the Program of Scientific and Technological Infrastructure of CONACYT, project code 268720, and the National Herbarium of Mexico MEXU for their help corroborating and identifying species of Pinus.

\section{Literatura citada}

Arriola-Padilla VJ, Estrada-Martínez E, Ortega-Rubio A, Pérez-Miranda R, Gijón-HernándezAR. 2014. Deterioro en áreas naturales protegidas del centro de México y del Eje Neovolcánico Transversal. Investigación y Ciencia 22: 37-49.

Bohlmann J. 2008. Insect-Induced Terpenoid Defenses in Spruce. In: Schaller A, eds. Induced Plant Resistance to Herbivory. Dordrecht: Springer, pp. 173-187. DOI: https://doi.org/10.1007/978-1-4020-8182-8_8

CONAFOR [Comisión Nacional Forestal]. 2010. Inventario Nacional Forestal y de Suelos: Manual y procedimientos para el muestreo de campo. Jalisco, México: Comisión Nacional Forestal. https://snigf.cnf.gob.mx/wp-content/uploads/Documentos\%20metodologicos/2010/Manual\%20remuestreo\%20infys \%202010 (accessed March 5, 2021).

Crawley MJ. 2013. The R book. West Sussex, United Kingdom: John Wiley and Sons. ISBN: 978-0-470-97392-9

Espejel A. 1996. La Malinche: una visión retrospectiva de su deterioro y conservación. Gaceta Ecológica 41: 14-21. Espejel-Rodríguez MMA, Santacruz-García N, Sánchez-Flores M. 1999. The use of oak in the region of La Malinche, State of Tlaxcala, Mexico. Botanical Sciences 64: 35-39. DOI: https://doi.org/10.17129/botsci.1580

Espejel-Rodríguez MMA, Santacruz-García N, Martínez-de la Fuente H. 2001. Explotación y Deterioro de los bosques de La Malinche, Estado de Tlaxcala. Instituto Nacional de Estadística y Geografía. Notas Revista de Información y Análisis 13:15-22.

Espejel-Rodríguez A, González-Torres IM, Perón-Delgado E. 2004. El índice de deterioro ambiental en los municipios de Tlaxcala: una propuesta metodológica. Gaceta Ecológica 70: 19-30.

Fa JE, Morales LM. 1991. Mammals and protected areas in the Trans-Mexican Neovolcanic Belt. In: Mares MA, 
Schmidly DJ, eds. Latin American mammalogy: history, biodiversity, and conservation. Oklahoma, USA: University of Oklahoma Press, pp.199-226. ISBN: 0-8061-2343-5

FAO [Food and Agriculture Organization]. 2018. El estado de los bosques del mundo- Las vías forestales hacia el desarrollo sostenible. Rome, Italy: Organización de las Naciones Unidas para la Alimentación y la Agricultura. ISBN: 978-92-5-130715-1

Farjón A, Pérez de la Rosa JA, Styles BT. 1997. Guía de campo de los pinos de México y América Central. London, United Kingdom: The Royal Botanic Gardens, Kew. ISBN: 978-1-900347-37-2

Ferrenberg S, Kane JM, Mitton JB. 2014. Resin duct characteristics associated with tree resistance to bark beetles across lodgepole and limber pines. Oecologia 174: 1283-1292. DOI: https://doi.org/10.1007/s00442-013-2841-2

Franceschi VR, Krokene P, Christiansen E, Krekling T. 2005. Anatomical and chemical defenses of conifer bark against bark beetles and other pests. New Phytologist 167: 353-376. DOI: https://doi.org/10.1111/j.1469$\underline{8137.2005 .01436 . x}$

Fritts HC. 1976. Tree rings and climate. London, New York and San Francisco:Academic Press. ISBN: 9780323145282

Galicia L, Potvin C, Messier C. 2015. Maintaining the high diversity of pine and oak species in Mexican temperate forests: a new management approach combining functional zoning and ecosystem adaptability. Canadian Journal of Forest Research 45: 1358-1368. DOI: https://doi.org/10.1139/cjfr-2014-0561

Gernandt DS, Pérez-de la Rosa JA. 2014. Biodiversidad de Pinophyta (coníferas) en México. Revista Mexicana de Biodiversidad 85: 126-133. DOI: https://doi.org/10.7550/rmb.32195

Gómez-Díaz JA, Villalobos F. 2020. Montañas: cómo se definen y su importancia para la biodiversidad y la humanidad. CIENCIA ergo-sum 27. DOI: https://doi.org/10.30878/ces.v27n2a9

Gutiérrez G, Ricker M. 2014. Manual para tomar virutas de madera con el barreno de Pressler en el Inventario Nacional Forestal y de Suelos. México, DF: Instituto de Biología, Universidad Nacional Autónoma de México. https://www.snieg.mx/DocAcervoINN/documentacion/inf_nvo_acervo/SNIGMA/Inv_Nac_For_Suelos/INFyS 2013 Anexo manual_virutas madera.pdf(accessed July 15, 2021).

Granados-Sánchez D, Ruíz-Puga P, Barrera-Escorcia H. 2008. Ecología de la herbivoria. Revista Chapingo. Serie Ciencias Forestales y del ambiente 14: 51-64.

Hadiyane A, Sulistyawati E, Asharina W, Dungani R. 2015. A Study on Production of Resin from Pinus merkusii Jungh. Et De Vriese in the Bosscha Observatory Area, West Java-Indonesia. Asian Journal of Plant Sciences 14: 89-93. DOI: https://doi.org/10.3923/ajps.2015.89.93

Halffter G, Morrone JJ. 2017. An analytical review of Halffter's Mexican transition zone, and its relevance for evolutionary biogeography, ecology and biogeographical regionalization. Zootaxa 4226: 1-46. DOI: https://doi. org/10.11646/zootaxa.4226.1.1

Hintze J. 2008. NCSS, PASS, GESS. Kaysville, Utah: NCSS. https://www.ncss.com/support/faq/ (accessed January $15,2021)$.

Kometter R. 2005. Manual de Censos Forestales. https://www.researchgate.net/profile/Roberto-Kometter/publication/317017325_MANUAL_DE_CENSO_FORESTAL/links/591f201d458515e3d4ff72b7/MANUAL-DECENSO-FORESTAL.pdf (accessed January 5, 2021).

Krommenhoek W, Sebus J, Van Esch GJ. 1986. Atlas de Histología Vegetal. Madrid: Marbán. ISBN: 8-7101-096-8.

Krokene P, Nagy NE, Solheim H. 2008. Methyl jasmonate and oxalic acid treatment of Norway spruce: anatomically based defense responses and increased resistance against fungal infection. Tree Physiology 28: 29-35. DOI: https://doi.org/10.1093/treephys/28.1.29

López-Rucuch R.1996. Comparación de dos métodos de resinación en Pinus oocarpa Schiede, P. montezumae Lambert y P. pseudostrobus Lindl., en la cuenca alta del río Chixoy, Guatemala MSc. Thesis, Centro Agronómico Tropical de Investigación y Enseñanza, Turrialba. Costa Rica.

López-Domínguez JC, Acosta-Pérez R. 2005. Descripción del Parque Nacional Malinche. In: Fernández-Fernández JA, López-Domínguez JC eds, Biodiversidad del Parque Nacional Malinche Tlaxcala, México. México: Coordinación General de Ecología del Gobierno del Estado de Tlaxcala, pp. 3-24. ISBN: 970-94333-0-X. 
Luchi N, Ma R, Capretti P, Bonello P. 2005. Systemic induction of traumatic resin ducts and resin flow in Austrian pine by wounding and inoculation with Sphaeropsis sapinea and Diplodia scrobiculata. Planta 221: 75-84. DOI: https://doi.org/10.1007/s00425-004-1414-3

Martínez M.1992. Los pinos mexicanos. México: Ediciones Botas. ISBN: 968-6334-19-X

Molina-Luna NG, Arellanes-Cancino Y. 2016. Intercambio de productos en mercados semanales de los Valles Centrales de Oaxaca, México. Etnobiología, 14: 92-99.

Montero-López C, Trabanino-García F, Varela-Scherrer CM, Liendo-Stuardo R. 2016. El manejo de un paisaje construido: aprovechamiento y explotación de los recursos vegetales y faunísticos en Chinikihá, Chiapas. Etnobiología 14: 5-22.

Moreira-Tomé X, Ramos-García MA, Sampedro-Pérez L, Zas-Arregui R, Solla-Hach A. 2008. Densidad y área de los canales resiníferos de Pinus pinaster ante tratamientos de fertilización y su relación con la defensa ante Hylobius abietis. Cuadernos de la Sociedad Española de Ciencias Forestales 26: 45-49.

Morrone JJ. 2019. Regionalización biogeográfica y evolución biótica de México: encrucijada de la biodiversidad del Nuevo Mundo. Revista Mexicana de Biodiversidad 90: 1-68. DOI: https://doi.org/10.22201/ ib.20078706e.2019.90.2980

Mumm R, Hilker M. 2006. Direct and indirect chemical defense of pine against folivorous insects. Trends in Plant Science 11: 351-358. DOI: https://doi.org/10.1016/j.tplants.2006.05.007

Nagy NE, Fossdal CG, Krokene P, Krekling T, Lönneborg A, Solheim H. 2004. Induced responses to pathogen infection in Norway spruce phloem: changes in polyphenolic parenchyma cells, chalcone synthase transcript levels and peroxidase activity. Tree Physiology 24: 505-515. DOI: https://doi.org/10.1093/treephys/24.5.505

Quintero-Gradilla SD, Jardel-Peláez EJ, Cuevas-Guzmán R, García-Oliva F, Martínez-Yrizar A. 2019. Cambio postincendio en la estructura y composición del estrato arbóreo y carga de combustibles en un bosque de Pinus douglasiana de México. Madera y Bosques 25:1-14 DOI: https://doi.org/10.21829/myb.2019.2531888

R Core Team (2015). R: A language and environment for statistical computing. R Foundation for Statistical Computing, Vienna, Austria. URL: https://www.R-project.org/.

Ramos-Dorantes DB, Villaseñor JL, Ortiz E, Gernandt DS. 2017. Biodiversity, distribution, and conservation status of Pinaceae in Puebla, Mexico. Revista Mexicana de Biodiversidad 88: 215-223. DOI: https://doi.org/10.1016/j. $\underline{\mathrm{rmb} .2017 .01 .028}$

Regil-García HH, Franco-Maass S, Endara-Agramont AR, Flamenco-Sandoval AF, Espinoza-Maya A, CalderónContreras R, Pérez-Vega BA. 2020. Procesos de pérdida y recuperación del contenido de carbono en biomasa aérea en las zonas forestales del área de protección de flora y fauna Nevado de Toluca en el periodo 2000-2013. Revista Geográfica de América Central 1: 203-233. DOI: https://doi.org/10.15359/rgac.64-1.8

Reyes-Ramos A, Sánchez-Vargas NM, Cruz de León J, Fabián-Plesníková I. 2016. Miniresinación Temprana de Pinus oocarpa Schiede ex Schltdl. en vivero. Biológicas 18: 36-39.

Romahn de la Vega CF, Ramírez MH. 2010. Dendrometría. México: Universidad Autónoma Chapingo, División de Ciencias Forestales. http://dicifo.chapingo.mx/pdf/publicaciones/dendrometria.pdf (accessed March 5, 2021).

Rodríguez-García A, López R, Martín JA, Pinillos F, Gil L. 2014. Resin yield in Pinus pinaster is related to tree dendrometry, stand density and tapping-induced systemic changes in xylem anatomy. Forest Ecology and Management 313: 47-54. DOI: https://doi.org/10.1016/j.foreco.2013.10.038

Rojas-García F, Villers-Ruíz L. 2005. Comparación de dos métodos para estimar la densidad de la madera de Pinus hartwegii Lindl. del Volcán La Malinche. Madera y Bosques 11: 63-71. DOI: https://doi.org/10.21829/ myb.2005.1111262

Rojas-García F, Villers-Ruíz L. 2008. Estimación de la biomasa forestal del Parque Nacional Malinche: TlaxcalaPuebla. Ciencia Forestal en México 33: 59-86.

Rzedowski J. 1978. Vegetación de México. México. DF: Limusa.

Rzedowski J. 2006. Vegetación de México. $1^{\text {a }}$ Edición digital. México: Comisión Nacional para el Conocimiento y Uso de la Biodiversidad. https://www.biodiversidad.gob.mx/publicaciones/librosDig/pdf/VegetacionMxPort.pdf (accessed July 11, 2021) 
Sampedro L, Moreira X, Zas R. 2011. Costs of constitutive and herbivore-induced chemical defences in pine trees emerge only under low nutrient availability. Journal of Ecology 99: 818-827. DOI: https://doi.org/10.1111/j.13652745.2011.01814.x

Sánchez-González A. 2008. Una visión actual de la diversidad y distribución de los pinos de México. Madera y Bosques 14: 107-120. DOI: https://doi.org/10.21829/myb.2008.1411222

Schlegel B, Gayoso J, Guerra J. 2001. Manual de procedimientos para inventarios de carbono en ecosistemas forestales. Valdivia, Chile: Universidad Austral de Chile. https://www.ccmss.org.mx/wp-content/uploads/2014/10/ Manual_de procedimiento para inventarios_de_carbono_en_ecosistemas_forestales.pdf (accessed July 13, 2021).

Schweingruber F. 1996. Tree Ring and Environment Dendroecology. Berna, Switzerland: Swiss Federal Institute for Forest, Snow and Landscape Research, WSL/FNP, Paul Haupt. ISBN: 3258054584

Suárez-Mota ME, Téllez-Valdés O, Lira-Saade R, Villaseñor JL. 2013. Una regionalización de la Faja Volcánica Transmexicana con base en su riqueza florística. Botanical Sciences 91: 93-105. DOI: https://doi.org/10.17129/ botsci.405

Speer JH, 2010. Fundamentals of tree-ring research. Arizona, USA: The University of Arizona Press. ISBN: 978-08165-2684-0

Vargas-Larreta B. 2013. Manual de mejores prácticas de manejo forestal para la conservación de la biodiversidad en ecosistemas templados de la región norte de México. México: Programa de las Naciones Unidas para el Desarrollo, Secretaría de Medio Ambiente y Recursos Naturales, Comisión Nacional Forestal y Rainforest Alliance. https:// biblioteca.semarnat.gob.mx/janium/Documentos/Ciga/Libros2014/CD001824.pdf (accessed July 10, 2021).

Veblen TT. 1982. Conservación forestal en el altiplano occidental de Guatemala. Mesoamérica 3: 332-355.

Villaseñor JL, Maeda P, Rosell JA, Ortiz E. 2007. Plant families as predictors of plant biodiversity in Mexico. Diversity and Distributions 13: 871-876. DOI: https://doi.org/10.1111/j.1472-4642.2007.00385.x

Villers-Ruiz L, Rojas-García F, Tenorio-Lezama P. 2006. Guía Botánica del Parque Nacional Malinche, TlaxcalaPuebla. México: Universidad Nacional Autónoma de México, Centro de Ciencias de la Atmósfera, Instituto de Biología. ISBN: 970-32-1844-X.

Werner G. 1990. La vegetación destruida en el altiplano Mexicano. Elementos 15: 9-25.

Zamora-Campos EM, Vázquez-Cuecuecha OG, Pérez-Ahuatzi A, Cano-Flores R, Aparicio-Rentería A, FernándezPedraza E. 2007. Variación natural de la densidad de la madera en Pinus montezumae Lamb. en tres altitudes del parque nacional la Malinche, Tlaxcala, México. Foresta Veracruzana 9: 33-38.

Zar JH. 1999. Biostatistical analysis. New Jersey, USA: Prentice Hall. ISBN: 0-13-086398-X

Zas R, Moreira X, Ramos M, Lima MRM, Nunes da Silva M, Solla A, Vasconcelos WM, Sampedro L. 2014. Intraspecific variation of anatomical and chemical defensive traits in Maritime pine (Pinus pinaster) as factors in susceptibility to the pinewood nematode (Bursaphelenchus xylophilus). Trees 29: 663-673. DOI: https://doi. org/10.1007/s00468-014-1143-6

Associate editor: Silvia Aguilar Rodríguez

Author contributions: GDC conducted the field and lab work, wrote the manuscript and took pictures; ARAH helped with the anatomical interpretation of results; SG loaned the field equipment, helped with fieldwork and statistical analysis; SPRA helped with statistical analysis and its interpretation; AME supported fieldwork and took pictures. All authors revised several versions of the manuscript and collaborated on the research design. 